\title{
Soil quality evaluation under different land use types in Kersa sub-watershed, eastern Ethiopia
}

Yared Mulat ${ }^{1 *}$, Kibebew Kibret ${ }^{2}$, Bobe Bedadi ${ }^{2}$ and Muktar Mohammed ${ }^{3}$

\begin{abstract}
Background: Soil quality, which can be inferred using indicators that interact synergistically, is affected by land use types and agricultural management practices. This study assessed the status of soil quality under three adjacent land uses (cultivated, grazing, and fallow) in Kersa subwatershed ( $622 \mathrm{ha})$. Soil samples were collected from the surface soil ( $0-20 \mathrm{~cm}$ depth) of the identified land uses with three replications and the soil quality parameters were analyzed. A minimum data set of soil quality indicators were selected from physical, chemical, and biological parameters using the literature review and expert opinion method. Linear scoring functions were used to give the unitless scores for the selected data sets, which were then integrated into a soil quality index (SQI).

Results: The results revealed that bulk density, aggregate stability, $\mathrm{pH}$, cation exchange capacity (CEC), available P, and soil organic carbon (SOC) had a significant difference in SQI among the different land uses. The soil quality indices were 0.69 for grazing land, 0.62 for cultivated land, and 0.59 for the fallow land. The SQI of all the land uses falls in the intermediate soil quality $(0.55<\mathrm{SQI}<0.70)$ class.

Conclusion: In almost all the quality indicators assessed, the grazing land was superior to the cultivated and fallow lands. Therefore, implementing management practices that enhance soil quality like organic matter-controlled systems is imperative for sustainable agricultural production in the study area.
\end{abstract}

Keywords: Soil quality, Minimum data set, Soil quality indicator, Land use

\section{Background}

Soils in agricultural production are a vital part of the ecological system which produces food and fiber for human utilization. Currently, sustainable and productive agriculture is highly related to soil quality (Karlen et al. 1997). Soil quality refers to the capacity of soil to function within ecosystem boundaries to sustain biological productivity, maintain environmental quality and, promote plant and animal health (Doran and Parkin 1994). Soil quality (SQ) addresses the issues of productivity

\footnotetext{
*Correspondence: yaredappo@gmail.com

1 Department of Natural Resource Management, Hawassa University, Wondo Genet College of Forestry and Natural Resources, P.O. Box 128, Shashemene, Ethiopia

Full list of author information is available at the end of the article
}

and sustainability simultaneously that's why currently it becomes so indispensable for developing countries.

Land use type and agricultural management can be considered as the major factors that affect soil quality as a result of the change it brings on the soil's physical, chemical, and biological properties (Caravaca et al. 2002). These changed properties, in turn, affect land productivity. That is the reason why Hartemink (2003) stated that soil degradation is the principal component of land degradation and almost all land degradation is caused by soil degradation. Land degradation is a serious threat in Sub-Saharan Africa, where nearly 67 percent of the total land is degraded from light to a severe extent (Sileshi et al. 2019). It is more severe in the highlands of Ethiopia where 85 percent of the population lives. Ethiopia is among the sub-Saharan African (SSA) countries with 
very high soil degradation rates most of it in the form of nutrient mining (Ermias et al. 2016; Misra et al. 2003).

In Ethiopia, total cultivated land has reached approximately 12 million hectares in mid-2013, but most of the soils are highly degraded ATA (2013). Out of the total land, the highlands of Ethiopia cover about $50 \%$ of the land area with $95 \%$ of the cropping land accounting for over $90 \%$ of the country's economy IFPRI (2010). This shows that the overwhelming majority of areas in the highlands are being put under intensive cropping. Moreover, new and often marginal and sloppy lands are being brought into crop production. Such land use changes have contributed to soil degradation and soil loss by deteriorating the soil's physical and chemical properties (Karltun et al. 2013). Land use practices affect the distribution and supply of soil nutrients by directly altering soil properties and by influencing biological transformations in the rooting zone. Furthermore, the high dependence on agriculture which is characterized by uncertain rainfall, poor management, and steep terrains, aggravates SQ degradation.

Soil quality degradation in Kersa sub-watershed, which is part of East Hararghe highlands, is uttered by the pressing problems of accelerated soil erosion, low productivity of agricultural lands, and deforestation (Bobe 2004; Kibebew 2014). In the study area, the land is used principally by smallholders for subsistence agriculture which is characterized by low yields and productivity. Since there are no such sustainable soil quality management practices in the study area, farmers always seek more land, whereby even the steep slopes and marginal lands are brought under cultivation to meet the increasing demand for food by the growing population. Hereafter, knowledge on SQ related to different land uses is imperative for developing management scenarios for sustainable use of the soil resource. This helps the farmers' endeavor towards sustainable and productive use of soils as well as improving the SQ.

Assessing and monitoring SQ in soils that are currently under different land use types can provide effective tools for determining the properties of degraded soils and revealing sustainable land practices for land managers, and decision-makers to make informed decisions against SQ degradation (Brhane 2014). However, as indicated by Diack and Stott (2001) soil quality cannot be measured directly but can be inferred by measuring soil physical, chemical, and biological properties that are used as quality indicators. Thus, the universally accepted soil quality index (SQI), which considers the soils' physical, chemical, and biological properties, and variability, is of paramount importance for sustainable utilization and site-specific management of soil resources. Despite such importance of soil quality index (SQI) assessment, few studies have been made to quantify the proper indicators for evaluating and monitoring soil quality in Ethiopia and most of them are conducted in the northern part of Ethiopia (Teklu et al. 2007; Gebreyesus 2014; Aweke et al. 2015; Yoseph et al. 2017). No attempt has been made to generate minimum data set and evaluate soil quality in the eastern part of Ethiopia.

Accordingly, assessing the soil quality status is imperative to design better soil management practices that enhance productivity and environmental sustainability. Besides, it helps planners and decision-makers to evaluate which land-use system is the most sustainable and to take appropriate remedial measures considering the potentials and constraints of the different land uses in the Kersa sub-watershed. Against this backdrop, the present study hypothesized that the different land-use types in Kersa sub-watershed are assumed to possess different soil quality due to differences in their physical, chemical, and biological soil attributes. Therefore, the objectives of this study were to establish a minimum data set (MDS) of soil quality indicators by selecting appropriate scoring functions for each indicator and evaluate soil quality of different land-use types using SQI.

\section{Materials and methods \\ Description of the study area}

The study area, Kersa sub-watershed, is located in Kersa district, East Hararghe zone of Oromia National Regional State between $9^{\circ} 26^{\prime} 28^{\prime \prime} \mathrm{N}$ and $9^{\circ} 27^{\prime} 50^{\prime \prime} \mathrm{N}$, and $41^{\circ} 52^{\prime} 0$ "E to $41^{\circ} 53^{\prime} 50^{\prime \prime} \mathrm{E}$ (Fig. 1) with altitude that ranges from 1968 to $2127 \mathrm{~m}$ above sea level. The total area of the watershed is 622 hectares.

Based on 21 years (1995-2015) of data obtained from the Ethiopian National Meteorology Agency (NMA), the study area receives a mean annual rainfall of $665 \mathrm{~mm}$. The rainfall pattern in the area is bi-modal with a high amount of rainfall occurring during the main rainy season between July to September and the short rainy season stretching from March to June (Fig. 2). The highest mean rainfall is received in August. Similarly, based on 18 (1997-2014) years of climate data obtained from NMA, the mean minimum and maximum annual air temperatures of the area are 12 and $24{ }^{\circ} \mathrm{C}$, respectively, with a mean annual air temperature of $18{ }^{\circ} \mathrm{C}$.

According to the geological map of Ethiopia, first published in 1973 at a scale of 1:2000000 and field observation the geology of Kersa district covered by Adigrat formation constituted by sandstones and shells. Hamanlei series formation that contains Oxfordian limestone covers the lower part of the landscape, while the upper part of the landscape is covered by the lower complex undifferentiated Precambrian rock. Moreover, Mohr (1964) indicated that Hararghe highlands lie over the 


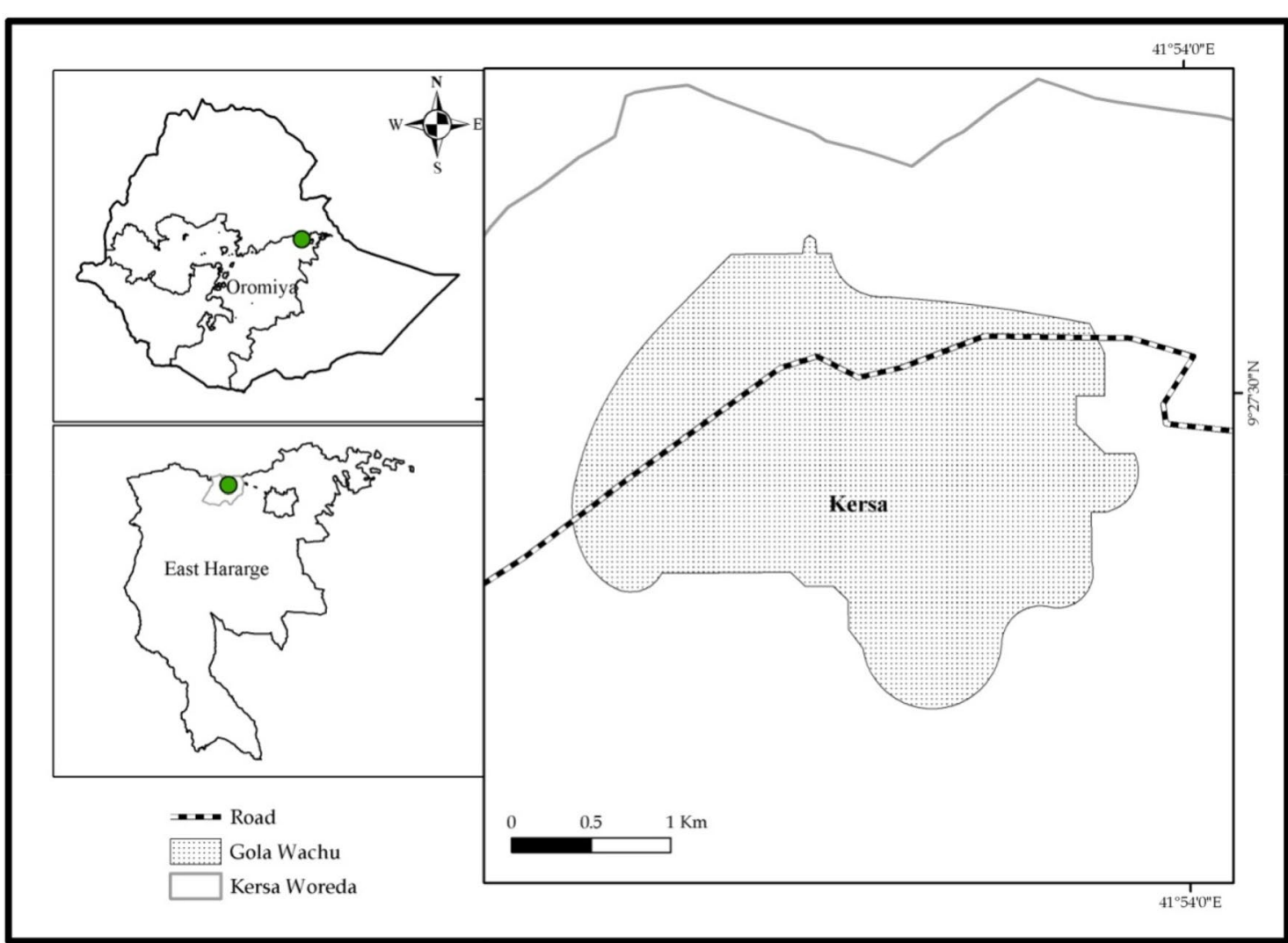

Fig. 1 Map of Kersa sub-watershed

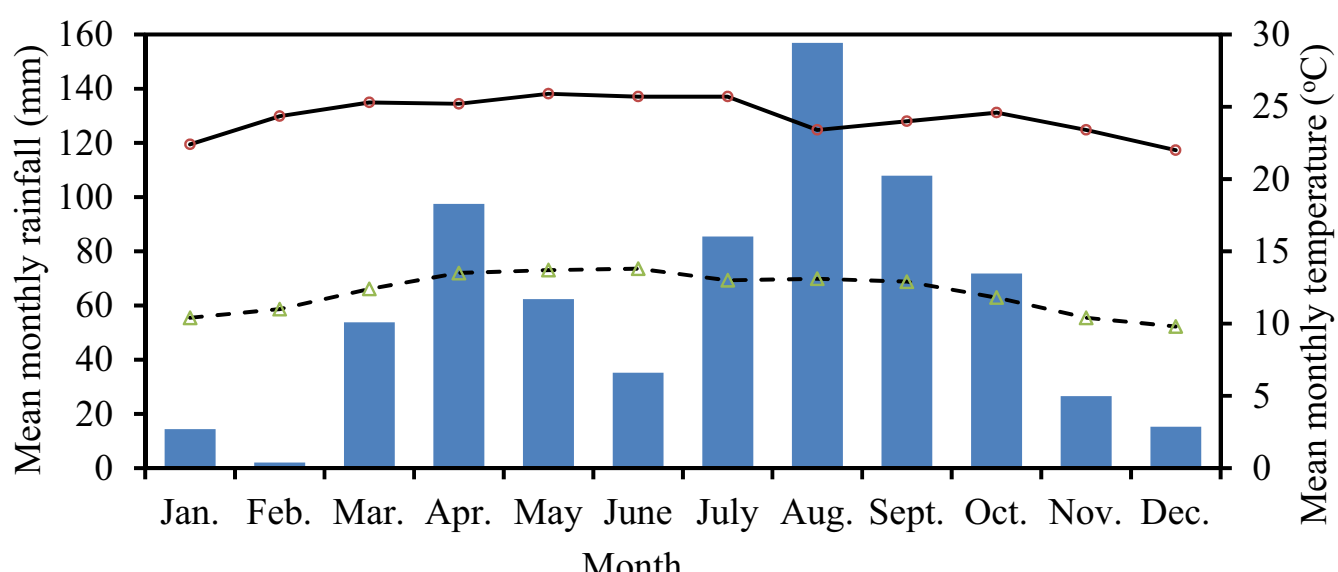

Mean Rainfall (mm) —-Mean Max $\left({ }^{\circ} \mathrm{C}\right)-₫-\operatorname{Mean} \operatorname{Min}\left({ }^{\circ} \mathrm{C}\right)$

Fig. 2 Mean monthly rainfall and mean monthly minimum and maximum temperatures of the study area

crystalline bedrock composed mainly of granitic rock and gneiss material. Although the study area encompasses different land use types, the dominant land uses observed during the study were grazing, cultivated, and fallow land use types (Table 1).

The farming system of the area is predominantly subsistence farming based on mixed crop-livestock 
Table 1 Description of land use types observed within Kersa sub-watershed in eastern Ethiopia

\begin{tabular}{lll}
\hline No Land use & Description \\
\hline $1 \quad$ Grazing $\quad \begin{array}{r}\text { The land is used as communal grazing land for cattle and it is managed through a controlled system whereby livestock is confined in a } \\
\text { stall and fed with a cut-and-carry system }\end{array}$ \\
$\begin{array}{l}\text { This includes land used for the cultivation of crops under rain-fed conditions. The main cropping system is mixed cropping where } \\
\text { khat (Catha edulis) is intercropped with sorghum. The only small amount of organic matter is returned to the soil, while almost no } \\
\text { crop residue is returned to the soil due to its use for other purposes such as animal feed, fuelwood, source of cash, and construction } \\
\text { material (e.g., sorghum) }\end{array}$
\end{tabular}

production. Livestock is an integral part of the farming system, supplying draught power for cultivation, food, and income to households. The major rain-fed field crops grown are sorghum and maize often intercropped with common bean and khat. Besides, around homesteads, the vegetation is dominated by Eucalyptus globules and Eucalyptus camaldulensis trees.

\section{Land use selection and soil sampling}

Before starting the reconnaissance survey and fieldwork, a preliminary interpretation of the topographic map of the study area $(1: 50,000)$ was made. The topographic map was used to identify preliminary land use, slope class, watershed boundary and to fix tentative sampling sites. After office works and before the opening auger holes, general field visual observation informal discussion with and a survey by transect walk and by the help of the map of the area was carried out to consolidate and determine representative sampling sites of the area. Furthermore, other relevant information was also gathered from different sources including the district agriculture bureau, and development agents, and informal group discussions with agricultural experts were conducted to identify the representative land-use types. Following the above-indicated activity, the exact field subwatershed boundary was demarcated and delineated with the help of a global positioning system. Accordingly, three adjacent landuse types: fallowed, cultivated, and grazing lands were selected. Purposive sampling method was used and selection for sampling considered adjacent land use types to minimize differences in climate, topography, geology, and soil type.

Soil samples were taken from the selected cultivated, fallow, and grazing land use types with three replications based on a sampling plot size of $10 \mathrm{~m}$ by $10 \mathrm{~m}$. At every sampling plot, five to seven subsamples from 0 to $20 \mathrm{~cm}$ depth were collected and mixed to form a composite sample.

All composite soil samples were mixed, quartered, and reduced to $1 \mathrm{~kg}$, and sealed with plastic bags. The disturbed soil samples collected were air-dried at room temperature, ground using mortar and pestle, and made to pass through a $2 \mathrm{~mm}$ sieve in the laboratory for all the soil parameters except for soil $\mathrm{OC}$ and total $\mathrm{N}$ before analysis. For the analysis of $\mathrm{OC}$ and total N, the soil samples were further passed through a $0.5 \mathrm{~mm}$ sieve. Undisturbed samples were taken with a core sampler. Finally, the soil samples were analyzed following standard analytical procedures.

\section{Soil analysis}

The soil physical properties analyzed include particle size distribution, bulk density, soil aggregate stability (SAS), infiltration, particle density, and porosity. Particle size distribution was determined by the Bouyoucos hydrometer method by Bouyoucos (1962) using sodium hexametaphosphate as a dispersing agent. Soil aggregate stability (SAS) was measured using the wet sieving method Kandeler (1996). It was then estimated as the mass of the aggregated soil remaining after wet sieving as a percent of the total mass of the soil without sand according to the formula:

$$
\% \mathrm{SAS}=\left[\frac{\left(\mathrm{M}_{2}-\mathrm{M}_{3}\right)}{\mathrm{W}-\left(\mathrm{M}_{3}-\mathrm{M}_{1}\right)}\right] \times 100
$$

where \% SAS, percentage of stable soil aggregates; M1, weight of the dish (g); M2, weight of the dish, stable aggregates, and sand (g); M3, weight of the dish and sand (g); (M2-M3), weight of stable aggregates; (M3-M1), weight of sand; W, total weight of the sample.

Infiltration was determined in the field with a double ring infiltrometer. Bulk density was determined from undisturbed (core) soil samples collected using a core sampler Black and Hartge (1986a, b). Particle density was determined by the graduated cylinder method (Issamand Antoine 2007). Finally, total porosity was estimated from bulk density $\left(\mathrm{BD}, \mathrm{g} / \mathrm{cm}^{3}\right)$ and particle density $\left(\mathrm{PD}, \mathrm{g} / \mathrm{cm}^{3}\right)$ values using the following formula:

$$
\text { Total porosity }(\%)=\left(1-\frac{\mathrm{BD}}{\mathrm{PD}}\right) \times 100
$$

The major soil chemical and biological properties analyzed were soil $\mathrm{pH}$, organic carbon $(\mathrm{OC})$, soil respiration, 
available $\mathrm{P}$, exchangeable bases $(\mathrm{Ca}, \mathrm{Mg}, \mathrm{Na}$, and $\mathrm{K})$, and cation exchange capacity (CEC). Soil $\mathrm{pH}$ and electrical conductivity were measured using a 1:2.5 soil to water ratio as described in Van Reeuwijk (1993). Organic carbon was determined using the wet oxidation method Walkley and Black (1934). Soil respiration was determined by Solvita soil respiration test kit as described by Woods End Laboratories (2015) which intended to show respiration under natural field moisture conditions. Available phosphorus was determined by using the Olsen method (Olsen et al. 1954).

Cation exchange capacity and exchangeable basic cations were extracted by $1 \mathrm{M}$ ammonium acetate ( $\mathrm{pH} 7)$. Soil CEC was measured after leaching the ammonium acetate extracted (ammonium ion saturated) soil samples with $10 \%$ sodium chloride solution. The $\mathrm{Na}^{+}$ions replace the $\mathrm{NH}_{4}{ }^{+}$ions in the sample and the amount of ammonium ion in the percolate was determined by the MicroKjeldahl procedures and reported as CEC method van Reeuwijk (1993). In the extract, exchangeable $\mathrm{Ca}$ and $\mathrm{Mg}$ were determined by atomic absorption spectrophotometer (AAS), while exchangeable $\mathrm{K}$ and $\mathrm{Na}$ were read by flame photometer. Extractable micronutrients ( $\mathrm{Fe}, \mathrm{Mn}$, $\mathrm{Cu}$, and $\mathrm{Zn}$ ) were extracted by diethylenetriaminepentaacetic acid (DTPA) method and were read using atomic absorption spectrophotometer (AAS) Lindsay and Norvell (1978).

\section{Calculation of soil quality index}

Soil quality indexing follows three basic steps. These steps are indicator selection, interpretation/scoring, and integration into soil quality index value.

\section{Indicator selection}

The general criteria used for SQ indicator selection included influence on soil production and sensitivity to environmental changes, eases and cost of sampling, and analysis method of the indicators to be selected. As a result selection of minimum data sets (MDS) of indicators was based on the method of expert opinion and reviews of previous studies. This is because Andrews et al. (2002) stated that expert opinion-based and statistical methods using principal component analysis (PCA) provided similar representative indicators as related to the measurement of environmental and production goals.

\section{Indicator interpretation}

The selected indicators were transformed into unit fewer scores ranging from 0 to 1 in a linear technique according to Diack and Stott (2001). Scores ranging from 0 to 1 were assigned to the indicators included in the MDS by applying the "more is better", "less is better" or "optimum is better" function. The scores were assigned based on soil function after deciding the linear relationship of the anticipated response (i.e., "less is better", "more is better" or "optimum better"). The score for each indicator was calculated after establishing the baseline, the lower, and the upper threshold values. The baseline value of the soil property corresponds to a score equal to 0.5 . In this study, threshold or limit values were assigned to each soil quality indicator from natural ecosystems, best-managed systems, and values adopted from literature (Table 2).

The equations of the score curves are as follows:

$$
\begin{aligned}
& f(x)=\left\{\begin{array}{c}
0.1 \\
0.9 * \frac{X-L}{U-L}+0.1 L \leq X \leq L \\
1 \\
X \geq U
\end{array}\right. \\
& f(x)=\left\{\begin{array}{c}
1 \\
1-0.9 * \frac{X-L}{U-L}+L \leq X \leq L \\
0.1 \\
X \geq U
\end{array}\right.
\end{aligned}
$$

where $\mathrm{f}(x)$ is the linear score; $x$ is the soil property value; and Land $U$ are the lower and upper threshold values, respectively. Equation 1 was used for the "more is better" scoring function, whereas Eq. 2 was used for the "less is better" function. For the "optimum is better" function, were scored as "more is better" for the increasing part and then scored as "less is better" for the decreasing part.

\section{Soil quality indexing}

Soil quality indicators are integrated into an index (SQI) by summing the scores from individual indicators obtained on each land use types and dividing by the total number of indicators as described by (Masto et al. 2008):

$$
\mathrm{SQI}=\left(\frac{\sum_{i=1}^{n} \mathrm{~S}_{i}}{\mathrm{n}}\right)
$$

where SQI is the soil quality index, Sis the linear scored value of individual indicators, and $n$ is the number of indicators included in the dataset. An SQI value close to 1 refers to the best functioning soil, while a zero (lower threshold) value refers to severely degraded soil. About this, Marzaioli et al. (2010) divided SQI into three grades. $\mathrm{SQI}<0.55$ was regarded as low soil quality; $0.55<\mathrm{SQI}<0.70$ was regarded as intermediate soil quality and $\mathrm{SQI}>0.70$ as high soil quality.

\section{Statistical analysis}

Measured data were subjected to analysis of variance (ANOVA) using the General Linear Model (GLM) procedure in which land use types were considered as independent variables (factors) and the selected soil properties as dependent variables. LSD was performed 


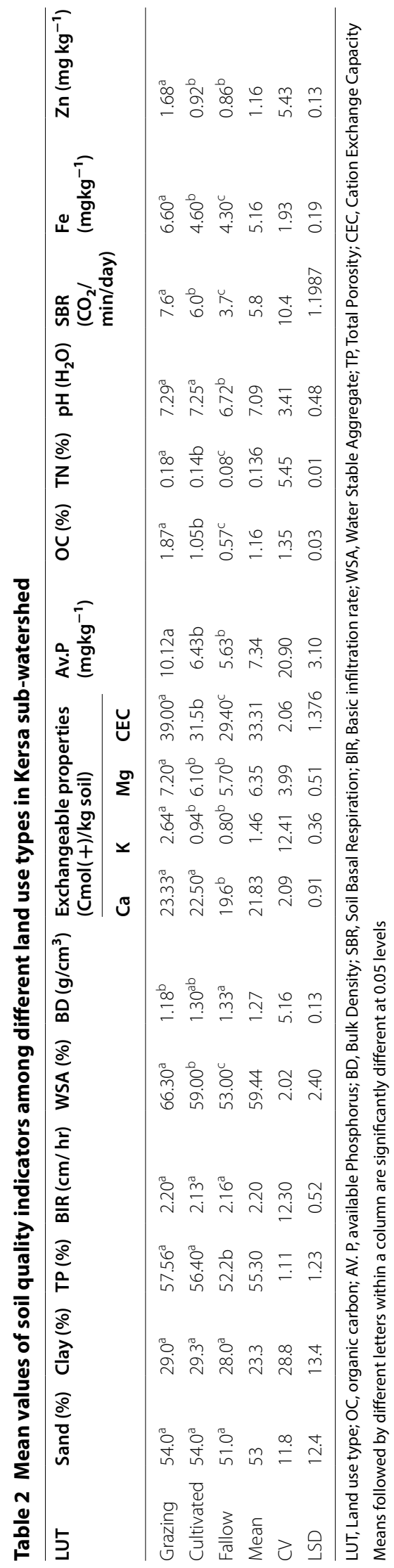


at $\mathrm{P}<0.05$ level using the statistical package SAS, Version 9.2.

\section{Results and discussion Effects of land use types on selected soil quality parameters \\ Soil physical quality indicators}

Soil texture attributes (sand, clay) and basic infiltration rate $(\mathrm{cm} / \mathrm{hr})$ exhibited no statistically significant difference among the different land use types in Kersa sub-watershed $(\mathrm{P}>0.05)$ (Table 2). Soil texture is an inherent soil property that is controlled primarily by soil formation processes Brejda et al. (2000b) and it is not influenced considerably by land use types and soil management in the short run. Rather, it is the major intrinsic factor that affects other soil properties such as infiltration albeit infiltration affected by land use types. As a result, it was rational that texture and infiltration rate exhibited statistically no significant difference among land use types in Kersa sub-watershed.

Bulk density, porosity, and aggregate stability were found to be statistically different in the different land use types. Table 2 indicates that bulk density was significantly higher in fallow land as compared to the grazing and cultivated lands. The highest bulk density in the fallow land could be a reflection of the low clay and amount of organic matter content which could also result in poor soil aggregation. The poor soil structure affects water intake and retention, which eventually results in soil quality degradation. On the other hand, the lower bulk density in grazing land due to the effect of high organic matter, which can give better structure or aggregation. A similar finding was reported by (Zhang et al. 2008).

Baseline and threshold reference value for bulk density determined by Harris et al. (1996) for natural ecosystems takes into account $1.5 \mathrm{~g} / \mathrm{cm}^{3}$ as baseline value above which there is an increasing probability of soil compaction (Table 3). About this value, the soil bulk density of the soils under the three land uses was within the optimal range. The total porosity (\%) of soils under the different land uses was significantly variable and ranged between 57 and 52 percent. The highest total porosity values were recorded under the grazing land use due to the low bulk density and high organic matter content.

Water stable aggregates were significantly affected by land use types $(\mathrm{P}<0.05)$. A higher percentage of aggregate stability was recorded in soils of grazing land (66.3\%) as compared to the other land use types (Table 2). This could be attributed to the relatively higher soil organic matter content. The finding confirms with Peng et al. (2015) who reported the contribution of soil organic matter in improving the formation of soil structure. Similarly, Yoseph et al. (2017) also reported that soil aggregate stability was significantly lower in cropland soils than in the soils under other land uses types.

\section{Soil chemical and biological quality indicators}

Soil $\mathrm{pH}$ was significantly $(\mathrm{P}<0.05)$ affected by land use type in which the lowest $\mathrm{pH}$ was recorded under the fallow land (Table 2). According to the soil pH ratings of (Tekalign 1991), the overall $\mathrm{pH}$ range of the studied soils falls under neutral soil reaction ranges, which are favorable for most macro and micronutrients and activities of microorganisms.

The significantly high $\mathrm{pH}$ in the grazing land could be attributed to the limited removal of basic cations through erosion and leaching. However, the removal of basic cations by crop through intensive cultivation, and continuous use of acid-forming inorganic fertilizers could be the reason for the lower soil $\mathrm{pH}$ in cultivated and fallow land

Table 3 Soil quality indicators, scoring function values, and references used for evaluating the soil quality indices in Kersa sub-watershed

\begin{tabular}{|c|c|c|c|c|c|c|c|}
\hline \multirow{2}{*}{$\begin{array}{l}\text { Source of limits } \\
\text { Clay }\end{array}$} & \multirow{2}{*}{$\begin{array}{l}\text { Scoring curve } \\
\text { More is better }\end{array}$} & \multicolumn{2}{|c|}{$\begin{array}{l}\text { Threshold } \\
\text { lower Upper }\end{array}$} & \multirow{2}{*}{$\begin{array}{l}\text { baseline } \\
15\end{array}$} & \multirow{2}{*}{$\begin{array}{l}\text { Optimum } \\
-\end{array}$} & \multirow{2}{*}{$\begin{array}{l}\text { Slope at baseline } \\
0.266\end{array}$} & \multirow{2}{*}{$\begin{array}{l}\text { Source of Threshold } \\
\text { Gebreyesus Brhane (2014) }\end{array}$} \\
\hline & & 0 & 30 & & & & \\
\hline Sand & Optimum & 0 & 60 & $\begin{array}{l}\text { Lo-30 } \\
\text { Up-50 }\end{array}$ & 36 & 0.44 & Gebreyesus Brhane (2014) \\
\hline Porosity (\%) & Optimum & 20 & 80 & $\begin{array}{l}\text { Lo }-40 \\
\text { Up- } 60\end{array}$ & 50 & 0.1280 & Karlen et al. (1994a, b) \\
\hline Aggregate stability \% & More is better & 10 & 60 & 30 & & 0.296 & Harris et al. (1996) \\
\hline Bulk density $\left(\mathrm{g} / \mathrm{cm}^{3}\right)$ & Less is better & 1.0 & 2.2 & 1.5 & & -2.62 & Harris et al. (1996) \\
\hline Av.P(mg kg $\left.{ }^{-1}\right)$ & More is better & 5 & 29 & 15 & & 0.433 & Mausbach and Seybold (1998) \\
\hline $\mathrm{CEC}\left(\mathrm{cmol}+\mathrm{kg}^{-1}\right)$ & More is better & 6 & 46 & 20 & & 0.245 & Gebreyesus Brhane (2014) \\
\hline $\mathrm{OC}(\%)$ & More is better & 1 & 6.5 & 3.5 & & 1.046 & Kay and Angers (1999) \\
\hline $\mathrm{pH}$ & Optimum & 4.5 & 9.5 & 6.5 & 5.3 & 1.3012 & Karlen et al. (1994a, b) \\
\hline
\end{tabular}


use types. The results are in agreement with the reports of Yihenew et al. (2015) who reported lower $\mathrm{pH}$ values for soils of cultivated lands and this ascribed to intensive cultivation and continuous use of acid-forming inorganic fertilizers.

The effect of land uses on available $\mathrm{P}$ was significant $(\mathrm{P}<0.05)$. Accordingly, significantly higher available $\mathrm{P}$ was recorded in soils under the grazing land as compared to those under cultivated and fallow land. The high organic matter content in the grazing land soils, which releases phosphorus during its mineralization, might contribute positively. These results are also in consonance with Solomon et al. (2001) and (Wakene and Heluf 2003) who reported that soil $P$ could be affected by vegetation cover in the land use. Nevertheless, the results of the present study were in contrast to that of (Alemayehu and Sheleme 2013) who obtained relatively higher available P under cultivated land than that of grassland soils. The authors attributed the higher concentration of available $\mathrm{P}$ found under cultivated land to long-term manure and house refuse applications.

Available P is below the baseline limit (Table 3). This low available $\mathrm{P}$ status might be attributed to low $\mathrm{P}$ fertilizer application and losses associated with erosion and removals during harvesting and continuous cropping and limited or no biomass return to the soil. The findings of this study are in agreement with the findings of (Girma and Endalkachew 2013) who indicated that low available phosphorus might be related to continuous cropping, surface erosion, and absence of biomass addition to the soils.

Analysis of variance revealed significant differences in CEC of soils under different land use types $(\mathrm{P}<0.05)$. The highest and lowest CEC values were recorded under grazing and fallow land uses, respectively. The high CEC in grazing land could be related to the combined effect and contribution of organic matter and types and amount of clay content in the soil. The result is in accordance with Bekele et al. (2006) who revealed that the CEC of soils changes due to change in land uses. Furthermore, Yihenew et al. (2015) and (Alemayehu and Sheleme 2013) pointed out that high cation exchange capacity (CEC) under grasslands was the result of high organic matter and clay content.

Soil organic carbon (SOC) showed significant variation with land use type $(\mathrm{P}<0.05)$. Accordingly, the highest organic carbon content was recorded under grazing land $(1.87 \%)$, while the lowest was observed in soils under the fallow land (Table 2). The lower soil organic carbon content under cultivated and fallow land could be related to the low amount of organic material being returned to the soil system and the high rate of oxidation of soil organic matter as a result of continuous cultivation for a long period. Correspondingly, the research under Ambo Ber, Northern Ethiopian by Yoseph et al. (2017) indicated that the grassland had significantly higher soil organic carbon than cropland. Nevertheless, the current finding is contrary to an earlier report by Boke (2004) who obtained a relatively higher content of organic carbon in cultivated land than that of grassland.

The baseline limit of OC is $3.5 \%$ (Table 3). About this limit, the OC content was far below the baseline limit in all land use types which indicates high biological soil quality degradation observed in the study soils. In line with this, Gebrayes et al. (2014) emphasized that the lower soil OC could result in poor aggregate stability and, thus, aggravates soil degradation.

\section{Soil quality index (SQI) of different land use types}

The selected minimum data set indicators for this study to calculate the SQI consisted of clay, sand, bulk density, aggregate stability, soil $\mathrm{pH}$, cation exchange capacity, SOC, and AvP. These indicators have also been consistently reported (Girmay and Singh 2012; Aweke et al. 2013; Cardoso et al. 2013). The scoring function of "more is better" used parameters like water-stable aggregates, organic carbon, clay content, CEC, and available P. On the other hand, bulk density was used as the "less is better" scoring function; while sand content and soil $\mathrm{pH}$ were used for the "optimum is better" scoring function.

The results ANOVA of the integrated soil quality index for the land uses were 0.69 for grazing land, 0.62 for cultivated land, and 0.59 for fallow land, all of which are classified into intermediate soil quality $(0.55<\mathrm{SQI}<0.70)$ class and statistically significant $(\mathrm{P}<0.05)$ (Table 4$)$. The soil quality index was found to be significantly higher in the grazing land use type as compared to the cultivated and fallow land uses. This reveals that the soils under the grazing land use type in kersa watershed are better off in terms of soil functioning and soil health (Andrews et al. 2003). The higher soil quality index for grazing land is due to the controlled grazing system. Also, grassroots contribute organic matter through their extended roots below the surface which are not easily decomposed (Guo and Gifford 2002). Thus, highly interrelated variables of high OC, good aggregate stability, low bulk density, higher $\mathrm{CEC}$, and available $\mathrm{P}$ yielded high soil quality index in the grazing land. On the other hand, the cultivated and fallow land use types scored intermediate but with relatively lower SQI values, which indicate the need for a judicious control of soil quality in the respective land use types (Nakajima et al. 2015).

In line with the findings of the current study, Girmay and Singh (2012) reported intermediate soil quality index values for grazing lands at Maileba and Gum Selassa catchments in northern Ethiopia. On the other hand, 
Table 4 Means of soil quality parameters' scores in the different land use types in Kersa sub-watershed

\begin{tabular}{lccccccccc}
\hline LU & Clay & Sand & WSA & OC & CEC & pH & BD & AV.P & SQI \\
\hline GR & $0.93^{\mathrm{a}}$ & $0.91^{\mathrm{a}}$ & $1.00^{\mathrm{a}}$ & $0.24^{\mathrm{a}}$ & $0.84^{\mathrm{a}}$ & $0.51^{\mathrm{b}}$ & $0.86^{\mathrm{a}}$ & $0.29^{\mathrm{a}}$ & $0.69^{\mathrm{a}}$ \\
$\mathrm{CL}$ & $0.90^{\mathrm{a}}$ & $0.91^{\mathrm{a}}$ & $0.98^{\mathrm{b}}$ & $0.11^{\mathrm{b}}$ & $0.67^{\mathrm{b}}$ & $0.50^{\mathrm{b}}$ & $0.78^{\mathrm{ab}}$ & $0.15^{\mathrm{b}}$ & $0.62^{\mathrm{b}}$ \\
FA & $0.92^{\mathrm{a}}$ & $0.87^{\mathrm{a}}$ & $0.87^{\mathrm{b}}$ & $0.03^{\mathrm{c}}$ & $0.63^{\mathrm{c}}$ & $0.59^{\mathrm{a}}$ & $0.75 \mathrm{~b}$ & $0.12^{\mathrm{b}}$ & $0.59^{\mathrm{b}}$ \\
Mean & 0.91 & 0.89 & 0.95 & 0.12 & 0.71 & 0.53 & 0.53 & 0.18 & 0.63 \\
LSD & 0.27 & 0.18 & 0.03 & 0.02 & 0.04 & 0.08 & 0.09 & 0.11 & 0.034 \\
CV & 14.9 & 10.4 & 1.72 & 2.03 & 2.16 & 8.17 & 6.16 & 29.2 & 2.24 \\
\hline
\end{tabular}

LU, Land Use; GR, Grazing Land; CL, Cultivated land; FA, Fallow Land; TP, Total Porosity; WSA, water-stable aggregate; CEC, Cation Exchange Capacity; BD, Bulk density; SQI, soil quality index; AvP, available Phosphorus

Means followed by different letters within a column are significantly different from each other at 0.05 levels

Gebreyesus (2014) reported a soil quality value index that is in the range of 'degraded' for uncultivated marginal land systems in the Mai-Negus catchment of northern Ethiopia. The findings also agreed with the results of similar previous studies conducted in the world NgoMbogba et al. (2015) where grasslands improved soil quality compared to continuous cultivation of crops.

The ANOVA result revealed that soil properties that explained the greatest proportion of the total variance in the present study included organic carbon, waterstable aggregates, $\mathrm{pH}, \mathrm{CEC}$, available Phosphorous, and bulk density (Table 4). These scored parameters made a significant difference among the different land use types $(\mathrm{P}<0.05)$. As a result, there was no need of analysing all soil quality indicators to monitor the change in the study sub-watershed these can lead to rapid and economical assessment. However, clay and sand content was the least important parameter in explaining the variability of soil quality since it did not statistically differ among land uses. This result is in agreement with the findings of Aweke et al. (2015) who identified soil organic carbon, water-stable aggregates, and cation exchange capacity and Girmay and Singh (2012) also identified bulk density and available phosphorous as soil properties influencing the integrated soil quality index in northern Ethiopia. Other similar findings were also reported by (Andrews et al. 2002; Tesfahunegn 2015).

\section{Conclusion}

Soil quality parameters are affected by several physicals, chemical, and biological parameters of the different land use types. Accordingly, statistically significant differences in soil quality of the different land uses were observed in the study area. The soil quality index of all land uses falls under the intermediate soil quality $(0.55<\mathrm{SQI}<0.70)$ class. The major parameters that affected the soil quality index among the different land use types were bulk density, aggregate stability, $\mathrm{pH}$,
CEC, available $\mathrm{P}$, and soil organic carbon. In most of the quality indicators assessed, the land under controlled grazing resulted in better quality as compared to the cultivated and fallow lands. Thus, the result of this study highlighted the potential of the land use types in improving or maintaining soil quality. Hence, locally appropriate soil fertility, productivity, and integrated soil conservation practices, and enhancing of soil organic matter and other attributes should be identified and implemented. These will contribute significantly to the maintenance of soil quality for sustainable agricultural production in the study area.

\section{Acknowledgments \\ The project was funded by Hawassa University and Haremaya University. Thus we would like to thank these institutions. We would also like to thank the anonymous reviewers who contributed significantly to the improvement of the article.}

\section{Authors' contributions}

YMT: collected, analyzed, interpreted the data, and made the final write up which was part of his Doctoral thesis in Soil Science at Haramaya University, Ethiopia. KKT, BBB, and MMK, as co-authors, edited the final manuscript. All authors read and approved the final manuscript.

\section{Funding}

Hawassa and Haremaya University provided funds for carrying out this study.

\section{Availability of data and materials \\ Not applicable.}

Ethics approval and consent to participate

"Not applicable".

Consent for publication

Not applicable.

Competing interests

The authors declare that they have no competing interests.

\section{Author details}

1 Department of Natural Resource Management, Hawassa University, Wondo Genet College of Forestry and Natural Resources, P.O. Box 128, Shashemene, Ethiopia. ${ }^{2}$ School of Natural Resources Management and Environmental Sciences, Haramaya University, P.O. Box 138, Dire Dawa, Ethiopia. ${ }^{3}$ Department of Forest Resources Management, Oda-Bultum University, P. O. Box 226, Chiro, Ethiopia. 
Received: 14 October 2020 Accepted: 15 February 2021

Published online: 24 February 2021

\section{References}

Agricultural Transformation Agency (2013) Annual report transforming agriculture in Ethiopia. Addis Ababa, Ethiopia

Alemayehu K, Sheleme B (2013) Effects of different land use systems on selected soil properties in South Ethiopia. J Soil Sci Environ Manag 4:100-107

Andrews S, Flora CB, Mitchell JP, Karlen DL (2003) Growers' perceptions and acceptance of soil quality indices. Geoderma 114:187-213

Andrews S, KarlenMitchell DJ (2002) A comparison of soil quality indexing methods for vegetable production systems in Northern California. Agric Ecosyst Environ 90:25-45

Aweke G, Singh B, Lal R (2013) Organic carbon and nitrogen associated with soil aggregates and particle sizes under different land uses in Tigray, Northern Ethiopia. Land Degrad Develop. https://doi.org/10.1002/ Idr.2261,2013

Aweke G, Singh B, Lal R (2015) Soil quality indices for evaluating smallholder agricultural land use in Northern Ethiopia. Sustainability 7:2322-2337

Bekele L, Kleja D, Nilsson I, Olsson M (2006) Soil carbon sequestration under different exotic tree species in the southwestern highlands of Ethiopia. Geoderma 136:886-898

Black G, Hartge KH (1986a) Bulk density in methods of soil analysis. In: Klute A (ed) Part 1. American Society of Agronomy-Soil Science Society of America, Madison, Wisconsin, USA, Physical and mineralogical methods, p 186

Black G, Hartge K (1986) Particle density. In: Klute A, ed. Methods of soil analysis. Madison: American Society of Agronomy, 1: 377-382.

BobeBedadi (2004) Evaluation of soil erosion in the Hararghe region of Ethiopia using soil loss models, rainfall simulation, and field trials (Ph.D. dissertation).The University of Pretoria, Pretoria, South Africa.

Boke S. (2004) Soil phosphorus fractions as influenced by different cropping systems in Andosols and Nitosols in Kembata-Tembaro and Wolayta Zones SNNPRS (MSc Thesis). Alemaya University, (AU) Ethiopia

Bouyoucus G (1962) Hydrometer method improvement for making particle size analysis of soils. Agron J 54:179-186

Brejda J, Moorman T, Karlen B, Dao T (2000) Identification of regional soil quality factors and indicators: I. Central and southern high plains. Soil Sci Soc Am J 64:2115-2124

Brhane T (2014) Soil quality assessment strategies for evaluating soil degradation in Northern Ethiopia. Appl Environ Soil Sci 14:64-78

Caravaca F, Masciandaro G, Ceccanti B (2002) Land use in relation to chemical and biochemical properties in the semiarid Mediterranean environment. Soil Till Res 68:23-30

Cardoso E, Vasconcellos RLF, Bini D, Miyauchi MYH, dos Santos CA, Alves, Diack M, Stott DE (2013) Development of soil quality index for the Chalmers silty clay loam from the Midwest USA, pp 550

Diack M, Stott D (2001) Development of soil quality index for the Chalmers silty clay loam from the Midwest USA, In: Stott DE, Mohtar RH, Steinhardt GC, eds. Sustaining the global farm, pp. 550-555.

Doran W, Parkin T (1994) Defining and assessing soil quality. Sustain Envir J 39:287-296

Ermias T, Woldeamlak B, Belay S (2016) Effects of land use and land cover on selected soil quality indicators in the headwater area of the Blue Nile basin of Ethiopia. Environ Monit Assess 188:83-95

Gebreyesus B (2014) Soil quality assessment strategies for evaluating soil degradation in Northern Ethiopia". Appl Environ Soil Sci 14:64-78

Girma A, Endalkachew W (2013) Soil properties, and soil organic carbon stocks of tropical andosol under different land uses. Open J Soil Sci 3:153

Girmay G, Singh B (2012) Changes in soil organic carbon stocks and soil quality: land-use system effects in northern Ethiopia. Act a AgriculturaeScandinavica and Section B Soil Plant Sci 62:519-530

Guo L, Gifford M (2002) Soil carbon stocks and land use change: a meta-analysis. Glob Change Biol 8:345-360

Harris R, Karlen L, Mulla D (1996) A conceptual framework for assessment and management of soil quality and health, in Methods for Assessing Soil Quality. In: Doranand JW, Jones AJ, eds, vol. 49. pp. 61-82, Soil Science Society of America, Madison, Wisconsin
HarteminkA (2003) Soil fertility decline in tropics with case studies on plantations walling ford: CAB international /ISRIC.

IFPRI (International Food Policy Research Institute) (2010) Fertilizer and soil fertility potential in Ethiopia Constraint and Opportunities for Enhancing the System. Working Paper. Addis Ababa, Ethiopia.

Issam I, Antoine H (2007) Methods of analysis for soils of the arid and semi-arid region. FAO

Kandeler E (1996) Aggregate stability. In: Schiner et al. eds. Methods in Soil biology. Berlin, Springer-Verlag. pp. 390-395

Karlen D, Mausbach M, Doran W, Cline H, Harris R, Schuman G (1997) Soil quality: a concept, definition, and framework for evaluation. Soil Sci Soc of Am J 61:4-10

Karlen D, Wollenhaupt NC, Erbach DC, Berry EC, Swan JB, Eash NS, Jordahl JL (1994a) Crop residue effects on soil quality following 10-years of no-till corn. Soil Tillage Res 31:149-167

Karlen L, Wollenhaupt ED, Berry C, Swan J, Eash N, Jordahl J (1994b) Long-term tillage effects on soil quality. Soil Tillage Res 32:313-327

Karltun E, Tekalign M, Taye B, Samuel G, Selamyihun K (2013) Towards improved fertilizer recommendations in Ethiopia Nutrient indices for categorization of fertilizer blends from woreda soil inventory data: A discussion paper. Ethiopian Agricultural Transformation Agency (ATA)/ Ethiopian Soil Information System (EthioSIS), Addis Ababa, Ethiopia.

Kay B, Angers D (1999) Soil structure. In: Summer ME (ed) Handbook of soil science. CRCPress, NewYork, pp 229-269

Kibebew K (2014) Report on Characterization of agricultural soils in Cascape intervention woredas in Eastern Region of Ethiopia, Haramaya University. Pp. 1-234

Lindsay WL, Norvel WA (1978) Development of DTPA soil test for zinc, iron, manganese and copper. Soil Sci Soc Am 42:421-428

Marzaioli R, D'Ascoli R, De Pascale R, Rutigliano F (2010) Soil quality in a Mediterranean area of Southern Italy as related to different land use types. J Appl Soil Ecol 44:205-212

Masto R, Chhonkar P, Singh D, Patra A (2008) Soil quality response to longterm nutrient and crop management on a semi-arid Inceptisol. Agric Ecosyst Environ 118:130-142

Mausbach M, Seybold C (1998) Assessment of soil quality". In: Lal R (ed) Soil quality and agricultural sustainability. Sleeping Bear Press, Chelsea, Mich, USA, pp 33-43

Misra R, Lesschen P, Smaling, Roy R (2003) Assessment of soil nutrient balance: approaches and methodologies (Vol. 14, FAO Fertilizer and Plant Nutrition Bulletin), Rome, Italy.

Mohr P (1964) Geology of Ethiopia. Asmara Printing Press, Asmara, Eritrea

Nakajima T, Lal R, Jiang SG (2015) Soil quality index of a cross by silt loam in central Ohio. Soil Tillage Res 146:323-328

Ngo-Mbogba M, Yemefack M, Nyeck B (2015) Assessing soil quality under different land cover types within shifting agriculture in South Cameroon. J Soil Tillage Res 150:124-131

Olsen S, Cole C, Watanabe S, Dean, (1954) Estimation of available phosphorous in soils by extraction with sodium bicarbonate. USDA Circular 939:1-19

Peng X, Yan X, Zhou H, Zhang Y, Sun H (2015) Assessing the contributions of sesquioxides and soil organic matter to aggregation in a ultisol under long-term fertilization. Soil Tillage Res 146:89-98

ReeuwijkV (1993) Procedures for soil analysis.4th ed. International Soil Reference and Information Center, The Netherlands

Sileshi M, Ruben K, Khamaldin M, Stafen S (2019) Determinants for adoption of physical soil and water conservation measures by smallholder farmers in Ethiopia. Int Soil Water Conserv Res. https://doi.org/10.1016/j.iswer .2019.08.002

Solomon D, Lehmann M, Tekaligh M, Fritzsche F, Zech W (2001) Sulfer fractions in particle size separation of the humid Ethiopia highland as influenced by land use changes. Geoderma 102:45-59

Tekalign T (1991) Soil, plant, water, fertilizer, animal manure, and compost analysis. International Livestock Research Center for Africa, Addis Ababa, Ethiopia, Working Document No, p 13

Teklu E, Itanna F, Stahr K (2007) Indexing soil quality: a new paradigm in soil science research. Aust J Soil Res 45:129-137

Tesfahunegn G (2015) Soil quality indicators response to land use and soil management systems in Northern Ethiopia's catchment. J Land Degrad Develop 27:438-448. https://doi.org/10.1002/ldr.2245 
Wakene N, Heluf G (2003) Forms of phosphorus and status of available micronutrients under different land-use systems of alfisols in Bako area of Ethiopia. Ethiopian J Nat Res 5:17-37

Walkley A, Black IA (1934) An examination of the digestion method for determining soil organic matter and proposed modification of the titration method. Soil Soc 37:29-35

Woods End Laboratories Inc (2016) Woods End Laboratories Inc. Mt Vernon. USA

Yihenew G, Fantanesh A, Solomon A (2015) The effect of land use types, management practices and slop classes on selected soil physicochemical properties in Zikre watershed, North-western Ethiopia. Open J Environ Syst Res 4:1-7
Yoseph I, Delelegn T, Witoon P, Amila B, BirruY TW, Hans G, Douglas L (2017) Changes in land use alter soil quality and aggregate stability in the highlands of northern Ethiopia. Sci Rep 7:13602

Zhang Y, Zhao Y, Shi X, Lu X, Yu D, Wang H, Sun D, Darilek J (2008) Variation of soil organic carbon estimates in mountain region: a case study from southwestern china. Geoderman 146:449-454

\section{Publisher's Note}

Springer Nature remains neutral with regard to jurisdictional claims in published maps and institutional affiliations.

\section{Submit your manuscript to a SpringerOpen ${ }^{\circ}$ journal and benefit from:}

- Convenient online submission

- Rigorous peer review

- Open access: articles freely available online

- High visibility within the field

- Retaining the copyright to your article

Submit your next manuscript at $\boldsymbol{\nabla}$ springeropen.com 